\title{
Issues in the Care and Treatment of HCV/HIV Co-Infection for Key Populations in Resource-Constrained Settings
}

\author{
Thomas F. Kresina, Robert Lubran, H. Westley Clark \\ Center for Substance Abuse Treatment, Substance Abuse and Mental Health Services Administration, Rockville, \\ USA \\ Email: tkresina@samhsa.gov
}

Received 15 May 2014; revised 26 June 2014; accepted 12 July 2014

Copyright (C) 2014 by authors and Scientific Research Publishing Inc.

This work is licensed under the Creative Commons Attribution International License (CC BY). http://creativecommons.org/licenses/by/4.0/

(c) (i) Open Access

\begin{abstract}
Globally, the epidemic of hepatitis virus infection is increasing in the context of common viral transmission routes with the Human Immunodeficiency Virus (HIV). Thus, co-infection with both hepatitis virus and HIV is becoming a common occurrence, particularly for key populations. Studies of key populations, people who inject drugs, sex workers, transgendered individuals and men having sex with men, report high levels of illicit drug and/or alcohol use along with limited access to health care and medical treatment. Without the medical management of co-occurring substance use disorders and hepatitis $C$ virus (HCV) infection, a significant proportion of this population with HCV/HIV co-infection will progress to chronic liver disease then subsequently end-stage liver disease. Thus, access to comprehensive care and treatment, including HCV testing with subsequent care and treatment of acute/chronic HCV infection is essential to address the global burden of disease. Increased efforts are needed globally to address the barriers to comprehensive care and treatment for key populations with HCV/HIV co-infection.
\end{abstract}

\section{Keywords}

Hepatitis C Infection, HIV, Substance Abuse Treatment, Care and Treatment, Key Populations

\section{Introduction}

The global epidemic of hepatitis infection has only recently been highlighted by the establishment of World Hepatitis Day, first occurring in 2008 [1]. Advances have followed with the 2010 World Health Assembly resolution recognizing the global health problem of hepatitis infection and the World Health Organization (WHO) 
creation of the Global Hepatitis Programme [2]. In 2012, the WHO provided a framework for global action on the prevention and control of viral hepatitis infection [3]. While providing a regional burden of disease, the framework presented a stark picture of hepatitis $\mathrm{C}$ infection in key populations, specifically for injection drug users, indicating that $60 \%-80 \%$ of injection drug users, worldwide, are positive for the hepatitis $C$ virus. The comprehensive framework for global action challenges regions and countries to develop specific strategies and plans to address the burden of hepatitis infection with important elements being the screening for hepatitis $\mathrm{C}$ infection and an increasing access to care and treatment. Critical to the success of these elements, in resourceconstrained settings, is the development of national hepatitis policies and care and treatment guidelines promoting accessible and affordable hepatitis $\mathrm{C}$ treatment. The WHO has recently published initial baseline survey data of 126 Member States, 60 of which were low-income countries, reporting on their comprehensive national response to hepatitis infection [4]. Only 47 countries report the presence of a written national strategy or plan for addressing hepatitis infection, while 36 Member States have a government unit dedicated to addressing hepatitis prevention, care and treatment. Approximately 90 countries have hepatitis prevention and control programs, but they mostly target health care workers. Sixty-nine counties report hepatitis prevention and control programs for injection drug users. Approximately 50 countries report a chronic hepatitis C surveillance program while 90 countries report surveys of chronic hepatitis infection in key populations. Access to care and treatment for hepatitis $\mathrm{C}$ is reported as limited, with 69 countries indicating the availability of pegylated interferon treatment. Ninety countries indicate some form of publicly funded hepatitis treatment program. The survey did not report the access and treatment levels for key populations.

\section{Key Populations, Illicit Drug and Alcohol Use and HCV/HIV Co-Infection}

The use and abuse of illicit drugs and alcohol are important considerations in HCV/HIV co-infection, particularly for key populations. Both high-risk sexual and drug injection behaviors provide common transmission routes for both HIV and HCV [5]. In the context of HIV transmission risk, it has been well established that both illicit drug use and alcohol use are important factors in promoting high-risk sex as well as increased numbers of sexual partners [6]-[8]. Illicit drug use also plays a role in the sexual transmission of HCV infection [9]. Recent studies on the culture of drug and alcohol use have shown that gender may play a role in the choice between alcohol versus illicit drug use and that substance use may be affiliated with the culture of specific key populations [10]. Nevertheless, individuals that use illegal drugs, or have a history of illegal drug use through injection, or have become addicted to illegal drug use, comprise a majority of HCV/HIV co-infected patients.

\subsection{People Who Inject Drugs}

For people who inject drugs, the risk for HCV/HIV co-infection is high. And indeed, people who inject drugs constitute the largest proportion within specific populations that are co-infected with HCV and HIV [11]. The sharing of injection drug related equipment and the increased number of sexual partners in the context of exchanging sex for drugs constituent behaviors providing common transmission routes for HIV and $\mathrm{HCV}$. Although HCV and HIV transmission can occur through unsafe injection practices, the relative efficiency of HCV transmission via injection drug use results in the likely scenario of blood-borne HCV infection with HIV infection resulting from high-risk sexual behavior [12]. Global epidemiology of HCV and HIV infection show people who inject drugs with higher infection rates of HCV compared to HIV [13]. Thus, in countries and regions where the global HIV epidemic is driven by injection drug use, rates of HCV/HIV co-infection in people who use drugs is high [11] [14] [15]. Also in these countries, chronic HCV infection is a leading cause of death, because HIV infection of individuals infected with HCV results in increased liver disease including cirrhosis and HCV-related mortality [12] [16].

Globally, key drug-using populations at risk for HCV/HIV co-infection include females who inject drugs and who trade sex for drugs, or who are sex partners of people who inject drugs, as well as young people who inject drugs, and people who use non-injection drugs [17]. For male injection drug users, paying for sex increased the risk of HCV/HIV infection, while for females having greater than three years of injection drug use, sharing equipment, and using alcohol with drugs was significant for co-infection. The importance of the age of first drink of alcohol for injection drug users is a predictor of co-infection through an increased number of sexual partners and early sexual debut [18]. It is also important to note the severe clinical consequences of consumption of alcohol in patients with HCV/HIV co-infection, namely the increase of liver disease including rapidly devel- 
oping cirrhosis and hepatocellular carcinoma [19]. Both cirrhotic liver disease and liver cancer have limited treatment options in resource constrained settings.

\subsection{Men Having Sex with Men}

For men having sex with men (MSM), the epidemiology of HCV/HIV co-infection is changing rapidly. Over the last ten years, numerous cohort studies have shown an increase in the incidence of acute HCV infection in MSM [20]-[24]. This increase is only partially due to parenteral exposure via illicit opioid injection or stimulant drug use [25] [26]. HCV transmission has been documented in MSM via mucosal exposure/sexual transmission [24] [27] [28]. This increase in HCV infection parallels an increase in HIV infection observed in cohorts of MSM from low and middle income countries [29]. Sentinel surveillance survey data from China, for example, have shown an increase in overall HIV prevalence among MSM populations from 0.9\% in 2003 to 6.3\% in 2011 [30]. The convergence of these increasing dual infections is alarming in a population that, in resource-limiting settings, is estranged from health care services. The result is a key population with increasing incident HCV/HIV co-infections without access to needed medical care and treatment.

Access to care and treatment for acute HCV/HIV infection is a significant missed opportunity to control viral hepatitis $\mathrm{C}$ infection. Acute HCV infection is defined as the first six months of HCV RNA detection in serum [31] [32]. In HCV/HIV co-infection, for cases with undetectable HCV, the presence of abnormal liver transaminase levels can be a diagnostic tool. Detection of acute HCV infection in the setting of HIV infection is important since, spontaneous clearance of the hepatitis infection has been reported to be high as $25 \%$ in cohort studies [33]. In addition, acute HCV infection in patients with HCV/HIV co-infection is treatment responsive to regimens of pegylated interferon and ribavirin [31]. Sustained viral response rates in cohort treatment studies have reported successful treatment of HCV infection ranging from 53\% to $82 \%$ of patients. Prevention and screening for HCV infection is fundamental in HIV-infected populations of MSM and for those found HCV positive, guideline recommended treatment regimens are appropriate for patients with acute HCV infection.

Illicit drug use and alcohol use in MSM populations in the context of the high-risk for HCV/HIV co-infection are noteworthy clinical issues in co-infection. As noted above, MSM frequently lack access to enabling medical care and treatment and the elevated use of drugs and alcohol may represent an effort to self-medicate due to the high level of stigma and discrimination [34]-[36]. Alternatively, drug and alcohol use may be affiliated with the culture of MSM and considered part of sexual practice [10]. In Thailand, a cross-sectional survey examining sexual risk behaviors among MSM showed one in five used illicit drugs [37], while other studies have shown a higher use of illicit drug use in MSM infected with HIV [38] [39]. Screening for alcohol consumption in a cohort of male sex workers reported 70\% consumed alcohol, $40 \%$ binge drank, 35\% screened for hazardous drinking, 15\% harmful drinking and 21\% alcohol dependence [40]. Taken together, these studies show the need to address drugs and alcohol use as HCV and HIV transmission risk-factors for MSM.

\subsection{Commercial Sex Workers}

Sex in exchange for drugs or valuables is a high-risk behavior for HIV infection. Studies have shown estimates for the prevalence of HIV infection in female sex workers to range from 31\% - 35\% [41] [42]. Many factors contribute to the HIV risk including stigma, migration, lack of access to condoms, injection drug use and sexual networks [43] [44]. Risk factors for the transmission of HCV are injection drug use and unprotected sex. Studies have shown that women living with HIV can acquire HCV infection through unprotected sex, suggesting a higher susceptibility [20] [45] [46]. Thus, female sex workers who use and abuse drugs and alcohol, as well as, sex workers who injection drugs invite the dual risk of HIV infection and HCV infection [47].

Substance use and abuse is a significant behavior in female sex workers and includes alcohol, stimulants and opioids [44] [48]-[50]. Substance use and HIV risk behaviors among female sex workers can differ significantly depending on work venues, and sex workers who use illicit drugs, can be characterized as: young, with low levels of self-esteem, or acquiring sexually transmitted infections and frequently engaged in unprotected vaginal sex with customers [51]. Qualitative interviews indicated that alcohol and drug use by female sex workers was due to their stressful life (e.g., long working hours and a large number of customers) and easy access to alcohol and drugs.

In Sub-Saharan Africa, multiple studies [52]-[58] have shown links between commercial sex work and 
drug use or alcohol use with the presence of multiple overlapping risk behaviors. These risk behaviors have the potential for increasing infectious disease transmission among persons in sexual and drug-using networks. Drug using female sex workers reported 3 - 10 clients per day, while drug using male sex workers reported 1 - 4 clients per day along with the use of drugs before, during and after sex. Drug use impaired safe sex practices and approximately one in three sex workers were noted to be infected with HIV. Alcohol-using female sex workers reported unsafe sexual practices, violence, and the presence of sexual transmitted diseases.

In Asia, studies have shown a similar intersection between illicit drug or alcohol use and commercial sex work. In India, of the four main pathways into sex work, obtaining money through sex work to purchase drugs or alcohol was second behind only poverty (the need to provide for self and/or family) [59]. Over two thirds of sex workers either chewed betal nut or consumed alcohol alone or with clients. Another study reported the use of illicit drugs with $78 \%$ being non-injecting drug users and $22 \%$ being injecting drug users [60]. Drug-using sex workers were significantly more likely to test positive for one or more sexually transmitted infections and were also significantly more likely to be currently married, widowed, or separated compared with non-drug-using female sex workers. In multiple logistic regression analysis, being an alcohol user, being married, having a larger volume of clients, and having sexual partners who have ever used or shared injecting drugs were found to be independently associated with illicit drug use. In China, screening of female sex works for alcohol consumption revealed that heavy drinkers had earlier sexual initiation, became involved in sex work at a young age, and used alcohol during sex, particularly in high-risk encounters [61]. Illicit drug use during commercial sex in China has been shown to be associated with HIV sero-positive status, initiating sex work at less than 20 years of age and working at high-risk establishments [62]. In Indonesia, cohort studies have shown that approximately $50 \%$ of female sex workers consume alcohol prior to interactions with clients, and those working at bars and discotheques are most frequent consumers of alcohol [63]. With the high prevalence of HCV/HIV co-infection risk behaviors (substance use and sexual risk) in the female sex worker population, more attention needs to be paid to the diagnosis, as well as care and treatment of HCV/HIV co-infection in this population.

\subsection{Transgendered Individuals}

There are very limited data with regard to HCV/HIV co-infection in the transgender community. Studies have shown a 7\% prevalence of HIV and HCV infection in a cohort from the Dominican Republic [64]; while HCV/ HIV co-infection among surveyed transgender sex workers in Argentina was 6.5\% [65]. In the transgender population, HCV infection has been associated with injection drug use while HIV infection has been associated with sex work [66]. However, transgender sex workers in Pakistan, have been reported to use alcohol during anal sex, while high levels of alcohol, marijuana, methamphetamine as well as illicit injection drug use, in the context of sex work, has been reported in transgender women in the United States [67] [68]. As cohort studies move forward, a clear picture of high substance use and high risk sex is common among transgender populations. These high-risk behaviors combined with a marginalized sexual or gender identity can result in a highly stigmatized environment to address the medical needs due to HCV/HIV co-infection [69].

\section{The Medical Management of Substance Use Disorders, HIV Infection and HCV Infection in the Context of HCV/HIV Co-Infection}

The medical management of HCV/HIV co-infection and associated co-morbidities is complex and challenging. It is more than just the management of HIV infection and HCV infection. The dual infection changes the natural history of each infection [70]. HCV infection of people living with HIV increases the risk of death due to liver-related disease or an AIDS-related illness [71] [72]. HIV infection, on the other hand, can accelerate the progression to cirrhosis, end-stage liver disease and HCV-related mortality [73]-[75]. Thus, HCV/HIV co-infection warrants aggressive treatment of both viral infections. This requires a proactive screening and diagnosis of individuals with high-risk behaviors, specifically key populations. Unfortunately, the stigma and discrimination toward key populations results in a medically disenfranchised population. Key populations do not routinely access medical care and treatment [76]. This results in key populations with HCV/HIV co-infection entering the medical care system with chronic end-stage liver disease or AIDS. For these individuals, life-saving medical services may be limited in low and middle resource countries. Enabling environments are needed to support their care 
and treatment and allow for key populations to access care and treatment early in the course of HCV/HIV coinfection.

Key populations interfacing and accessing medical care and treatment can be greatly facilitated by peer outreach [77]. In addition, peer outreach workers can provide an accommodating environment to screen for high risk-behaviors. With the elevated use of drugs and alcohol in key populations, screening for substance use disorders in an import initial step that can be facilitated by peer outreach workers. A positive screening for a substance use disorder can provide a platform to address early on other co-morbidities such as HIV infection and HCV infection. Treatment of persons co-infected with HCV and HIV is best managed by a team of health care providers and specialists who are expert in dealing with HCV infection, infectious diseases, mental health, addiction medicine and social issues in a step-by-step approach [78]. However, this may not always be possible in limited resource settings, which clearly shows the importance of early access of available medical care and treatment to promote better clinical outcomes for HCV/HIV co-infection in key populations. This starts with addressing substance use disorders and patient education promoting stabilization from which other medical care and treatments addressing HIV and HCV infections can successfully proceed [79].

\subsection{Substance Abuse Treatment for Substance Use Disorders}

Since substance abuse is a complex disorder composed of multiple physiologic, social and behavioral problems, with optimal treatment attending to all aspects [80]. Most effective is a "whole person treatment" that includes behavioral, biological (pharmacological) and social rehabilitative components [81]. Behavioral interventions have been extensively researched and are critical components of the treatment of all drug addictions. Pharmacological treatments have been developed, approved and available for nicotine, alcohol, and opiates, but none are available for stimulants, like cocaine or methamphetamine [82]. An effective way to treat drug abuse and dependence is to match a comprehensive treatment plan to the individual's particular substance abuse problems and needs. Desired treatment outcomes are: 1) reduced dependence on drug of abuse, 2) reduced morbidity and mortality associated with drug of abuse, and 3) a maximized patient's ability to access services and achieve social integration.

\subsubsection{Behavioral Interventions for Substance Use Disorders}

Non-pharmacologic substance abuse treatments, which have been extensively researched, are only recently being recognized as important tools for health care providers. These multidisciplinary interventions target various aspects of substance use disorders, including the craving of substances of abuse, the driving force behind addiction. Behavioral interventions also attempt to interrupt the ability of environmental cues and stressful experiences that trigger relapse, as well as, enhance the patient's abilities to interact appropriately with the family, the work setting, and in the community. Early interventions have been developed and can be provided in controlled settings by trained health care providers. Brief interventions show promise as a practical, low intensity intervention for substance use that can be utilized by community peer outreach workers [82]. The features of the low intensity interventions are: 1) they are used for 1 to 3 visits (low intensity), 2) they are used for early drug use, and 3) they may be used in many different settings. Utilizing brief interventions and other motivational enhancement methods, in early drug use, appear particularly well suited for the primary care setting and resource limited settings [82].

Behavioral drug treatment approaches that result in successful outcomes have been shown to follow key research-based principles of effective drug treatment [83]. These principles include: 1) providing readily available and accessible treatment when needed, 2) recognizing that drug use and dependence are chronic conditions, 3) recognizing that relapses can occur during and after successful treatment episodes, 4) understanding that detoxification is a precursor of treatment rather than a modality in and of itself, 5) establishing and following a comprehensive treatment plan, and 6) remaining in treatment for an adequate period of time. Behavioral therapy and counseling approaches are critical components of effective treatment because they help patients to develop skills that resist drugs, replace drug-using activities with constructive and rewarding activities, and improve problemsolving abilities [84]. Treatment programs for key populations can be most effective by providing behavioral therapies as part of a continuum of care in a supportive, empathic, primary care settings [81] [82].

\subsubsection{Pharmacologic Treatments for Substance Use Disorders}

Treatment of substance use disorders using pharmacotherapeutic approaches are based on targeted drug devel- 
opment of inhibitors of the biochemically-based, physiologic pathways of addiction [85]. Addictive drugs utilize neurological pathways and receptor-ligand interactions in the brain to modify behavior [86]. Effective medications for maintenance treatment of opioid dependence include methadone and buprenorphine, which are either full or partial opioid receptor antagonists [80]. Recently, extended-release naltrexone, an opioid antagonist, has been approved for the prevention of relapse to opioid use for individuals after detoxification from opioids [87].

For key populations with HCV/HIV co-infection, an important intervention for injection opioid abuse is medication-assisted treatment, utilizing methadone [80] [81]. Methadone is the preferred pharmacotherapy for resource limited setting because of its lower cost compared to other medications. Globally since 2000, there has been a rapid expansion of medication-assisted treatment, mainly using methadone, in the context of HIV prevention, care and treatment programs [88]. The integration of substance abuse treatment and HIV care and treatment is an effective and cost efficient health service platform to provide care and treatment for HCV/HIV co-infection in a resource limiting setting [89].

Limited data are available on the prevalence of HCV/HIV co-infection in patients receiving methadone maintenance treatment. Cohort studies present values between 4.6\% and 13.1\% [90] [91]. Factors associated with co-infection for patient receiving methadone maintenance treatment are young age, longer time of heroin use and sharing of injection equipment [92] [93]. Methadone treatment programs provide a venue for not only screening for HIV and HCV infection among drug users in resource limited settings, but also stabilizing the patient with a substance use disorder to enhance access to HCV treatment and HIV treatment [94] [95]. Promoting the access to antiretroviral treatment for key populations, particularly injection drug users, is important because a recent systematic review showed that globally, people who inject drugs and living with HIV are less likely to receive anti-retroviral treatment compared to people living with HIV who do not use drugs [95] [96].

\subsection{HIV Care and Treatment}

Access to HIV care and treatment is fundament for good clinical outcomes in the medical management of HCV/ HIV co-infection. Anti-retroviral treatment reduces AIDS-related mortality by changing terminal HIV infection into a chronic disease, as long as patients are adherent to the pharmacological regimen and remain in care [97]. While HCV/HIV co-infection enhances the risk of drug induced hepatotoxicity, combination anti-retroviral therapy has been shown to slow liver disease progression and reduce liver-related mortality due to HCV infection [98]. An important factor here appears to be CD4 count, where individuals with higher ( $>200)$ cell counts at the time of treatment have a lower mortality rate [99]. These data again point to the importance of early access to HIV care and treatment to reduce the progression of liver disease in HCV/HIV co-infected patients. In most cases, HIV care and treatment, including combination anti-retroviral treatment should precede HCV treatment [70] [100]. The response to combination anti-retroviral therapy in HCV/HIV co-infected patients is comparable to HIV mono-infected patients in terms of HIV viral suppression and AIDS-free survival [101]. The most effective way to reduce morbidity and mortality from liver disease in HCV/HIV co-infected patients is to treat these patients for their HCV infection as part of HIV care.

\subsection{HCV Treatment in the Era of Direct-Acting Anti-Viral Drugs}

Treatment of HCV infection in persons with HCV/HIV co-infection is an urgent issue due to rapidly progressive liver disease [102]. While anti-retroviral treatment for HIV infection slows the rapid progression of liver disease in co-infected patients, the treatment does not eliminate the progressive liver disease. International treatment guidelines endorse the consideration of HCV treatment for all HCV/HIV co-infected individuals in order to obtain a sustained viral response [103] [104]. A sustained viral response to HCV treatment reduces liver fibrosis, hepatotoxicity, and liver-related mortality [70]. However, the obtainment of a sustained viral response to HCV treatment using interferon-based regimens is lower in HCV/HIV co-infection than in HCV mono-infection. The rates of obtaining a sustained viral response in large treatment trials range from $14 \%$ - 38\% [105]. Noting the poor treatment response with interferon-based treatment regimens, the difficult side effects of treatment, and the long treatment period combined with the stigma, discrimination and estrangement from the mainstream medical community of key populations, the current treatment regimen for HCV infection is not a practical therapy for eliminating HCV infection in co-infected key populations.

Enter the rapidly evolving new treatment medications for HCV infection, termed direct acting antivirals [70] [106] [107]. The first two direct acting anti-virals were protease inhibitors and their approval occurred in 2011 
for use in genotype 1 mono-infected patients [106]. These protease inhibitors were used in combination with interferon-based treatment regimens virtually doubling the sustained virologic response rate. The initial full report of these first generation protease inhibitors in key populations co-infected with HCV and HIV showed a response rate of $84 \%$ after only 12 weeks of treatment [108]. Many other clinical trials of direct acting antivirals have been presented at clinical conferences with similar success rates and limited side effects, but also showing potentially serious drug interactions with medications comprising antiretroviral treatment of HIV infection [109] [110]. It is hoped that these drug interaction can be managed, because clinical trials and treatment guidelines are being developed for direct acting anti-retroviral medications that may include combination direct-acting antivirals for HCV/HIV patients not responsive to mono-therapy [111]-[113]. What remains are clinical trials and population treatment studies of key population who inject drugs, as well as, clinical trials comprising key populations receiving methadone treatment. In addition, these newly developed medications need to be priced in a range that can have a public health impact on key populations who are co-infected with HCV/HIV infections.

\section{References}

[1] World Hepatitis Alliance (2008) World Hepatitis Day 2008. http://www.worldhepatitisalliance.org/en/world-hepatitis-day-2008.html

[2] World Health Organization (WHO) (2010) Global Hepatitis Programme. http://www.who.int/csr/disease/hepatitis/en/

[3] World Health Organization (WHO) (2012) Prevention \& Control of Viral Hepatitis Infection: Framework for Global Action. http://www.who.int/csr/disease/hepatitis/Framework/en/index.html

[4] World Health Organization (WHO) (2013) Global Policy Report on the Prevention and control of Viral Hepatitis in Member States. http://www.who.int/csr/disease/hepatitis/global_report/en/index.html

[5] Gupta, P. (2013) Hepatitis C Virus and HIV Type 1 Co-Infection. Infectious Disease Report, 5, e7.

[6] Wechsberg, W.M., Golin, C., El-Bassel, N., Hopkins, J. and Zule, W. (2012) Current Interventions to Reduce Sexual Risk Behaviors and Crack Cocaine Use among HIV-Infected Individuals. Current HIV/AIDS Report, 9, 385-393. http://dx.doi.org/10.1007/s11904-012-0131-y

[7] Friedman, S.R., Mateu-Gelabert, P. and Sandoval, M. (2011) Group Sex Events amongst Non-Gay Drug Users: An Understudied Risk Environment. International Journal on Drug Policy, 22, 1-8. http://dx.doi.org/10.1016/j.drugpo.2010.06.004

[8] Zuckerman, M.D. and Boyer, E.W. (2012) HIV and Club Drugs in Emerging Adulthood. Current Opinions in Pediatrics, 24, 219-224. http://dx.doi.org/10.1097/MOP.0b013e32834faa9b

[9] Alter, M.J. (2011) HCV Routes of Transmission: What Goes around Comes Around. Seminars in Liver Diseases, 31, 340-346. http://dx.doi.org/10.1055/s-0031-1297923

[10] Green, K.E. and Feinstein, B.A. (2012) Substance Use in Lesbian, Gay and Bisexual Populations: An Update on Empirical Research and Implications for Treatment. Psychology and Addiction Behavior, 26, 265-278. http://dx.doi.org/10.1037/a0025424

[11] Matthews, G.V. and Dore, G.J. (2008) HIV and Hepatitis C Coinfection. Journal of Gastroenterology and Hepatology, 23, 1000-1008.

[12] Taylor, L.E., Swan, T. and Mayer, K.H. (2012) HIV Coinfection with Hepatitis C Virus: Evolving Epidemiology and Treatment Paradigms. Clinical Infectious Diseases, 55, S33-S42. http://dx.doi.org/10.1093/cid/cis367

[13] Nelson, P.K., Mathers, B.M., Cowie, B., Hagan, H., Des Jarlais, D., Horyniak, D. and Degenhardt, L. (2011) Global Epidemiology of Hepatitis B and Hepatitis C in People Who Inject Drugs: Results of Systematic Reviews. Lancet, 378, 571-573. http://dx.doi.org/10.1016/S0140-6736(11)61097-0

[14] Johnston, L., Saumtall, A., Corceal, S., Mahadoo I. and Oodally, F. (2011) High HIV and Hepatitis C Prevalence amongst Injection Drug Users in Mauritius: Findings from a Population Size Estimate and Respondent Driven Sampling Survey. International Journal on Drug Policy, 22, 252-258. http://dx.doi.org/10.1016/j.drugpo.2011.05.007

[15] Panda, S., Roy, T., Pahari, S., Mehraa, J., Sharma, N., Singh, G., Singh, J., Joseph, F., Singh, S. and Sharma, N.M. (2013) Alarming Epidemics of Human Immunodeficiency Virus and Hepatitis C Virus among Injection Drug Users in the Northwestern Bordering State of Punjab, India: Prevalence and Correlates. International Journal on Sexual Transmitted Diseases and AIDS.

[16] de Lédinghen, V., Barreiro, P., Foucher, J., Labarga, P., Castéra, L., Vispo, M.E., et al. (2008) Liver Fibrosis on Account of Chronic Hepatitis C Is More Severe in HIV-Positive than HIV-Negative Patients Despite Antiretroviral Therapy. Journal of Viral Hepatitis, 15, 427-433. http://dx.doi.org/10.1111/j.1365-2893.2007.00962.x

[17] El-Bassel, N., Shaw, S.A., Dasgupta, A. and Strathdee, S.A. (2014) Drug Use as a Driver of HIV Risks: Re-Emerging 
and Emerging Issues. Current Opinion in HIV and AIDS, 9, 150-155. http://dx.doi.org/10.1097/COH.0000000000000035

[18] Abdala, N., Hasen, N.B., Toussova, O.V., Krasnoselskikh, T.V., Kozlov, A.P. and Heimer, R. (2012) Age at First Alcoholic Drink as a Predictor of Current HIV Sexual Risk Behaviors among a Sample of Injection Drug Users (IDUs) and Non-IDUs Who Are Sexual Partners of IDUs, in St. Petersburg, Russia. AIDS Behavior, 16, 1597-1604. http://dx.doi.org/10.1007/s10461-011-0013-0

[19] Prakask, O., Mason, A., Luftig, R.B. and Bautista, A.P. (2002) Hepatitis C Virus (HCV) and Human Immunodeficiency Virus Type 1 (HIV-1) Infections in Alcoholics. Frontiers in Biological Sciences, 7, e286-e300.

[20] Danta, M. and Rodger, A.J. (2011) Transmission of HCV in HIV-Positive Populations. Current Opinion in HIV and AIDS, 6, 451-458. http://dx.doi.org/10.1097/COH.0b013e32834b4974

[21] Wandeler, G., Gsponer, T., Bregenzer, A., Gunthard, H.F., Clerc, O., Calmy, A., Stockle, M., Bernasconi, E., Furrer, H., Rauch, A. and the Swiss HIV Cohort Study (2012) Hepatitis C Virus Infections in the Swiss HIV Cohort Study: A Rapid Evolving Epidemic. Clinical Infectious Diseases, 55, 1408-1416. http://dx.doi.org/10.1093/cid/cis694

[22] Gambotti, L. (2005) Acute Hepatitis C Infection in HIV Positive Men Who Have Sex With Men in Paris, Francis 20012004. European Surveillance, 10, 115-117.

[23] Matthews G.V., Hellard, M., Kaldor, J. and Dore, G. (2007) Further Evidence of HCV Sexual Transmission among HIV-Positive Men Who Have Sex With Men: Response to Danta et al. AIDS, 21, 2112-2113. http://dx.doi.org/10.1097/QAD.0b013e3282ef3873

[24] Yaphe, S., Bozinoff, N., Kyle, R., Shivkumar, S., Pai, N.P. and Klein, M. (2012) Incidence of Acute Hepatitis C Virus Infection among Men Who Have Sex with Men with and without HIV Infection: A Systematic Review. Sexually Transmitted Infections, 88, 558-564. http://dx.doi.org/10.1136/sextrans-2012-050566

[25] Morano, J.P., Gibson, B.A. and Altice, F.L. (2013) The Burgeoning HIV/HCV Syndemic in the Urban Northeast: HCV, HIV, and HIV/HCV Coinfection in an Urban Setting. PLOS ONE, 8, e64321. http://dx.doi.org/10.1371/journal.pone.0064321

[26] Lea, T., Lee, E., Mao, L., de Wit, J. and Holt, M. (2013) HIV and Hepatitis C Virus Co-Infection among Men Who Have Sex with Men in Sydney, and Associations with Sexual and Drug Use Practices. Sexual Health, 10, 448-451. http://dx.doi.org/10.1071/SH13042

[27] Mahony, A.A., Donnan, E.J., Lester, R.A., Doyle, J.S., Knox, J., Tracy, S.L., Bowden, S. and Sasadeusz, J.J. (2013) Beyond Injecting Drug Use: Investigation of a Victorian Cluster of Hepatitis C among HIV-Infected Men Who Have Sex with Men. Medical Journal of Australia, 198, 210-214. http://dx.doi.org/10.5694/mja12.10556

[28] Gamage, D.G., Read, T.R., Bradshaw, C.S., Hocking, J.S., Howley, K., Chen, M.Y. and Farley, C.K. (2011) Incidence of Hepatitis-C among HIV Infected Men Who have Sex with Men (MSM) Attending a Sexual Health Service: A Cohort Study. BMC Infectious Diseases, 11, 39. http://dx.doi.org/10.1186/1471-2334-11-39

[29] Beyer, C., Sullivan, P., Sanchez, J., Baral, S.D., Collins, C., Witz, A.L., Altman, D., Trapence, G. and Mayer, K. (2013) The Increase in Global HIV Epidemics in MSM. AIDS, 27, 2665-2678. http://dx.doi.org/10.1097/01.aids.0000432449.30239.fe

[30] Li, X.F., Lu, H.Y., Cox, C., Zhao, Y.J., Xia, D.Y., Sun, Y.M., He, X., Xiao, Y., Ruan, Y., Jia, Y.J. and Shao, Y. (2014) Changing the Landscape of the HIV Epidemic among MSM in China: Results from Three Consecutive RespondentDriven Sampling Surveys from 2009-2011. BioMedical Research International, 2014, Article ID 563517.

[31] Boesecke, C. and Rockstroh, J.K. (2012) Acute Hepatitis C in Patients with HIV. Seminars in Liver Diseases, 32, 130137. http://dx.doi.org/10.1055/s-0032-1316468

[32] Boesecke, C. and Vogel, M. (2011) HIV and Hepatitis C Co-Infection: Acute HCV Therapy. Current Opinion in HIV AIDS, 6, 459-464. http://dx.doi.org/10.1097/COH.0b013e32834b87de

[33] Boesecke, C. and Rockstroh, J.K. (2011) Treatment of Acute Hepatitis C Infection in HIV-Infected Patients. Current Opinion in HIV \& AIDS, 6, 278-284. http://dx.doi.org/10.1097/COH.0b013e32834732cd

[34] Breyer, C., Sullivan, P.S., Sanchez, J., Dowdy, D., Altman, D., Trapence, G., Collins, C., Katabira, E., Kazatchkine, M, Sidibe, M. and Mayer, K.H. (2012) A Call to Action for Comprehensive HIV Services for Men Who Have Sex with Men. The Lancet, 380, 424-438. http://dx.doi.org/10.1016/S0140-6736(12)61022-8

[35] Stroumsa, D. (2014) The State of Transgender Health Care: Policy, Law and Medical Frameworks. American Journal of Public Health, 104, e31-e38. http://dx.doi.org/10.2105/AJPH.2013.301789

[36] Wolf, R.C., Cheng, A.S., Kapesa, L. and Castor, D. (2013) Building the Evidence Base for Urgent Action: HIV Epidemiology and Innovative Programming for Men Who Have Sex with Men in Sub-Saharan Africa. Journal of the International AIDS Society, 16, 18903. http://dx.doi.org/10.7448/IAS.16.4.18903

[37] Newman, P.A., Lee, S.J., Roungprakhon, S. and Tepjan, S. (2012) Demographic and Behavioral Correlates of HIV 
Risk among Men and Transgender Women Recruited from Gay Entertainment Venues and Community-Based Organizations in Thailand: Implications for HIV Prevention. Prevention Science, 13, 483-492.

http://dx.doi.org/10.1007/s11121-012-0275-4

[38] Li, Y., Baker, J.J., Korostyshevskiy, V.R., Slack, R.S. and Plankey, M.W. (2012) The Association of Intimate Partner Violence, Recreational Drug Use with HIV Seroprevalence among MSM. AIDS Behavior, 16, 491-498. http://dx.doi.org/10.1007/s10461-012-0157-6

[39] Wei, C., Guadamuz, T.E., Lim, S.H., Huang, Y. and Koe, S. (2012) Pattern and Level of Illicit Drug Use among Men Who Have Sex with Men in Asia. Drug and Alcohol Dependence, 120, 246-249. http://dx.doi.org/10.1016/j.drugalcdep.2011.07.016

[40] Luchters, S., Giebel, S., Syengo, M., Lango, D., King’ola, N., Temmerman, M. and Chersich, M.F. (2011) Use of AUDIT, and Measures of Drinking Frequency and Patterns to Detect Association between Alcohol and Sexual Behavior in Male Sex Workers in Kenya. BMC Public Health, 11, 384-390. http://dx.doi.org/10.1186/1471-2458-11-384

[41] Baral, S., Beyrer, C., Muessig, K., Poteat, T., Wirtz, A.L., Decker, M.R., Sherman, S.G. and Kerrigan, D. (2012) Burden of HIV among Female Sex Workers in Low-Income and Middle-Income Countries: A Systematic Review and Meta-Analysis. The Lancet Infectious Diseases, 12, 538-549. http://dx.doi.org/10.1016/S1473-3099(12)70066-X

[42] Papworth, E., Ceesay, N., An, L., Thiam-Niagoin, M., Ky-Zerbo, O., Holland, C., Frame, F.M., Grosso, A., Diouf, D. and Baral, S.D. (2013) Epidemiology of HIV among Female Sex Workers, Their Clients, Men Who Have Sex with Men and People Who Inject Drugs in West and Central Africa. Journal of the International AIDS Society, 16, 18751.

[43] Shannon, K., Goldenberg, S.M., Deering, K.N. and Strathdee, S.A. (2014) HIV Infection among Female Sex Workers in Concentrated and High Prevalence Epidemics: Why a Structural Dominants Framework Is Needed. Current Opinion in HIV \& AIDS, 9, 174-182. http://dx.doi.org/10.1097/COH.0000000000000042

[44] Baral, S., Todd, C.S., Aumakham, B., Lloyd, J., Delegchoimbol, A. and Sabin, K. (2013) HIV among Female Sex Workers in the Central Asian Republics, Afghanistan, and Mongolia: Contexts and Convergence with Drug Use. Drug and Alcohol Dependence, 132, S13-S16. http://dx.doi.org/10.1016/j.drugalcdep.2013.07.004

[45] Cainelli, F. (2013) Hepatitis C Virus and Human Immunodeficiency Virus Transmission Routes: Differences and Similarities. World Journal of Hepatology, 5, 234-236. http://dx.doi.org/10.4254/wjh.v5.i5.234

[46] Frederick, T., Burian, P., Terrault, N., Cohen, M., Augenbraun, M., Young, M., et al. (2009) Factors Associated with Prevalent Hepatitis C Infection among HIV-Infected Women with No Reported History of Injection Drug Use: The Women’s Interagency HIV Study (WIHS). AIDS Patient Care and STDs, 23, 915-923. http://dx.doi.org/10.1089/apc.2009.0111

[47] El-Bassel, N., Wechsberg, W.M. and Shaw, S.A. (2012) Dual Risk and Vulnerabilities among Women Who Use or Inject Drugs: No Single Prevention Strategy Is the Answer. Current Opinion in HIV \& AIDS, 7, 326-331. http://dx.doi.org/10.1097/COH.0b013e3283536ab2

[48] Li, Q., Li, X. and Stanton, B. (2010) Alcohol Use among Female Sex Workers and Male Clients: An Integrative Review of Global Literature. Alcohol and Alcoholism, 45, 188-199. http://dx.doi.org/10.1093/alcalc/agp095

[49] Lyons, T., Kerr, T., Duff, P., Feng, C. and Shannon, K. (2014) Youth, Violence and Non-Injection Drug Use: Nexus of Vulnerabilities among Lesbian and Bisexual Sex Workers. AIDS Care, 26, 1090-1094.

[50] Marhall, B.D., Wood, E., Shoveller, J.A., Patterson, T.L., Montaner, J.S. and Kerr, T. (2011) Pathways to HIV Risk and Vulnerability among Lesbian, Gay, Bisexual, and Transgendered Methamphetamine Users: A Multi-Cohort Gender-Based Analysis. BMC Public Health, 11, 20. http://dx.doi.org/10.1186/1471-2458-11-20

[51] Nemoto, T., Iwamoto, M., Sakata, M., Perngparn, U. and Areesantichai, C. (2012) Social and Cultural Contexts of HIV Risk Behaviors among Thai Female Sex Workers in Bangkok, Thailand. AIDS Care, 25, 613-618. http://dx.doi.org/10.1080/09540121.2012.726336

[52] Chersich, M.F., Luchters, S.M., Malonza, I.M., Mwarogo, P., King’ola, N. and Temmerman M. (2007) Heavy Episodic Drinking among Kenyan Female Sex Workers Is Associated with Unsafe Sex, Sexual Violence and Sexually Transmitted Infections. International Journal of Sexually Transmitted Diseases and AIDS, 18, 764-769.

[53] Chersich, M.F., Luchters, S., Ntaganira, I, .Gerbase, A., Lo, Y.R., Scorgie, F. and Steen, R. (2013) Priority Interventions to Reduce HIV Transmission in Sex Work Settings in Sub-Saharan Africa and Delivery of These Services. Journal of the International AIDS Society, 16, 17980. http://dx.doi.org/10.7448/IAS.16.1.17980

[54] Mumtaz, G.R., Weiss, H.A., Thomas, S.L., Riome, S., Setayesh, H., Riedner, G., Semini, I., Tawil, O., Akala, F.A., Wilson, D. and Abu-Raddad, L.J. (2014) HIV among People Who Inject Drugs in the Middle East and North Africa: Systematic Review and Data Synthesis. PLoS Medicine, 11, Article ID: e1001663. http://dx.doi.org/10.1371/journal.pmed.1001663

[55] Needle, R., Kroeger, K., Belani, H., Achrekar, A., Parry, C.D. and Dewing, S. (2008) Sex, Drugs, and HIV: Rapid Assessment of HIV Risk Behaviors among Street-Based Drug Using Sex Workers in Durban, South Africa. Social Sci- 
ence Medicine, 67, 1447-1455.

[56] Parry, C.D., Petersen, P., Carney, T., Dewing, S. and Needle, R. (2008) Rapid Assessment of Drug Use and Sexual HIV Risk Patterns among Vulnerable Drug Using Populations in Cape Town, Durban and Pretoria, South Africa. SAHARA Journal, 5, 113-119. http://dx.doi.org/10.1080/17290376.2008.9724909

[57] Parry, C.D., Plüddemann, A., Louw, A. and Leggett, T. (2004) The 3-Metros Study of Drugs and Crime in South Africa: Findings and Policy Implications. The American Journal of Drug and Alcohol Abuse, 30, 167-185. http://dx.doi.org/10.1081/ADA-120029872

[58] Wechsberg, W.M., Wu, L.T., Zule, W.A., Parry, C.D., Browne, F.A., Luseno, W.K., Kline, T. and Gentry, A. (2009) Substance Abuse, Treatment Needs and Access among Female Sex Workers and Non-Sex Workers in Pretoria, South Africa. Substance Abuse Treatment, Prevention, and Policy, 4, 1-11. http://dx.doi.org/10.1186/1747-597X-4-11

[59] Raut, D.K., Pal, D. and Das, A. (2003) A Study of HIV/STD Infections amongst Commercial Sex Workers in Kolkata (India) Part II: Sexual Behavior, Knowledge and Attitude towards STD/HIV Infections. Journal of Communicable Diseases, 35, 182-187.

[60] Medhi, G.K., Mahanta, J., Kermode, M., Paranjape, R.S., Adhikary, R., Phukan, S.K. and Ngully, P. (2012) Factors Associated with History of Drug Use among Female Sex Workers (FSW) in a High Prevalence State of India. BMC Public Health, 12, 273. http://dx.doi.org/10.1186/1471-2458-12-273

[61] Chen, Y., Li, X., Zhang, C., Hong, Y., Zhou, Y. and Liu, W. (2013) Alcohol Use and Sexual Risks: Use of Alcohol Use Disorders Identification Test (AUDIT) among Female Sex Workers in China. Health Care of Women International, 34, 122-138. http://dx.doi.org/10.1080/07399332.2011.610535

[62] Wang, H., Brown, K.S., Wang, G., Ding, G., Zang, C., Wang, J., Reilly, K.H., Chen, H. and Wang, N. (2011) Knowledge of HIV Seropositvity Is a Predictor for Illicit Drug Use: Incidence of Drug Use Initiation among Female Sex Workers in a High HIV-Prevalence Area of China. Drug and Alcohol Dependence, 117, 226-232. http://dx.doi.org/10.1016/j.drugalcdep.2011.02.006

[63] Safika, I., Timothy, P., Johnson, T.P. and Levy, J.A. (2011) A Venue Analysis of Predictors of Alcohol Use Prior to Sexual Intercourse among Female Sex Workers in Senggigi, Indonesia. International Journal of Drug Policy, 22, 4955. http://dx.doi.org/10.1016/j.drugpo.2010.09.003

[64] Johnston, L.G., Vaillant, T.C., Dolores, Y. and Vales, H.M. (2013) HIV, Hepatitis B/C and Syphilis Prevalence and Risk Behaviors among Gay, Transsexuals and Men Who Have Sex with Men, Dominican Republic. International Journal of Sexually Transmitted Diseases and AIDS, 24, 313-321.

[65] Carobene, M., Bolcic, F., Farias, M.S., Quarleri, J. and Ávila, M.M. (2014) HIV, HBV, and HCV Molecular Epidemiology among Trans (Transvestites, Transsexuals, and Transgender) Sex Workers in Argentina. Journal of Medical Virology, 86, 64-70. http://dx.doi.org/10.1002/jmv.23805

[66] Nuttbrock, L., Hwahng, S., Bockting, W., Rosenblum, W., Mason, M., Macri, M. and Becker, J. (2009) Lifetime Risk Factors for HIV/Sexually Transmitted Infections among Male-to-Female Transgender Persons. JAIDS Journal of the Acquired Immune Deficiency Syndrome, 52, 417-421. http://dx.doi.org/10.1097/QAI.0b013e3181ab6ed8

[67] Altaf, A., Zahidie, A. and Agha, A. (2012) Comparing Risk Factors of HIV among Hijra Sex Workers in Larkana and Other Cities of Pakistan: An Analytical Cross Sectional Study. BMC Public Health, 12, 279. http://dx.doi.org/10.1186/1471-2458-12-279

[68] Reback, C.J. and Fletcher, J.B. (2013) HIV Prevalence, Substance Use, and Sexual Risk Behaviors among Transgender Women Recruited Through Outreach. AIDS \& Behavior, 18, 1359-1367.

[69] Deacon, R.M., Mooney-Somers, J., Treloar, C. and Maher, L. (2013) At the Intersection of Marginalised Identities: Lesbian, Gay, Bisexual and Transgender People’s Experience of Injecting Drug Use and Hepatitis C Seroconversion. Health and Social Care in the Community, 21, 402-410. http://dx.doi.org/10.1111/hsc.12026

[70] Taylor, L.E., Swan, T. and Matthews, G.V. (2013) Management of Hepatitis C Virus/HIV Coinfection among People Who Use Drugs in the Era of Direct-Acting Antiviral-Based Therapy. Clinical Infectious Diseases, 57, S118-S124. http://dx.doi.org/10.1093/cid/cit326

[71] Herando, V., Prerez-Cachafeiro, S., Lewden, C., Gonzalez, J., Segura, F., Oteo, J.A., et al. (2012) All-Cause and LiverRelated Mortality in HIV Positive Subjects Compared to the General Population: Differences by Co-Infection. Journal of Hepatology, 57, 743-751. http://dx.doi.org/10.1016/j.jhep.2012.06.010

[72] van der Helm, J., Geskus, R., Sabin, C., Meyer, L., del Amo, J., Chêne, G., et al. (2013) Effect of HCV Infection on Cause-Specific Mortality after HIV Seroconversion, before and after 1997. Gastroenterology, 144, 751-760. http://dx.doi.org/10.1053/j.gastro.2012.12.026

[73] Graham, C.S, Baden, L.R., Yu, E., Mrus, J.M., Carnie, J., Heeren, T. and Koziel, M.J. (2001) Influence of Human Immunodeficiency Virus Infection on the Course of Hepatitis C Virus Infection: A Meta-Analysis. Clinical Infectious Diseases, 33, 562-569. http://dx.doi.org/10.1086/321909 
[74] De Lédinghen, V., Barreiro, P., Foucher, J., Labarga, P., Castéra, L., Vispo, M.E., Bernard, P.H., Martin-Carbonero, L., Neau, D., García-Gascó, P., Merrouche, W. and Soriano, V. (2008) Liver Fibrosis on Account of Chronic Hepatitis C Is More Severe in HIV-Positive than HIV-Negative Patients Despite Antiretroviral Therapy. Journal of Viral Hepatitis, 15, 427-433. http://dx.doi.org/10.1111/j.1365-2893.2007.00962.x

[75] Weber, R., Sabin, C.A., Friis-Moller, N., Reiss, P., El-Sadr, W.M., Kirk, O., Dabis, F., Law, M.G., Pradier, C., De Wit, S., Akerlund, B., Calvo, G., Monforte, A., Rickenbach, M., Ledergerber, B., Phillips, A.N. and Lundgren, J.D. (2006) Liver-Related Deaths in Persons Infected with the Human Immunodeficiency Virus: The D:A:D Study. Archives of Internal Medicine, 166, 1632-1641. http://dx.doi.org/10.1001/archinte.166.15.1632

[76] Scorgie, F., Nakato, D., Harper, E., Richter, M., Maseko., Nare, P., Smit, J. and Chersich, M. (2013) "We Are Despised in the Hospitals”: Sex Workers’ Experience of Accessing Health Care in Four African Countries. Culture, Health \& Sexuality, 15, 450-465. http://dx.doi.org/10.1080/13691058.2012.763187

[77] Deering, K.N., Kerr, T., Tyndall, M.W., Montaner, J.S., Gibson, K., Irons, L. and Shannon, K. (2011) A Peer-Led Mobile Outreach Program and Increased Utilization of Detoxification and Residential Drug Treatment among Female Sex Workers Who Use Drugs in a Canadian Setting. Drug and Alcohol Dependence, 113, 46-54. http://dx.doi.org/10.1016/j.drugalcdep.2010.07.007

[78] Soriano, V., Puoti, M., Sulkowski, M., Mauss, S., Cacoub, P., Cargnel, A., Dieterich, D., Hatzakis, A. and Rockstroh, J. (2004) Care of Patients with Hepatitis C and HIV Co-Infection. AIDS, 18, 1-12. http://dx.doi.org/10.1097/00002030-200401020-00001

[79] Mehta, S.H., Genberg, B.L., Astemborski, J., Kavasery, R., Kirk, G.D., Vlahov, D., Strathdee, S. and Thomas, D.L. (2008) Limited Uptake of Hepatitis C Treatment among Injection Drug Users. Journal of Community Health, 33, 126133. http://dx.doi.org/10.1007/s10900-007-9083-3

[80] Bruce, R.D., Kresina, T.F. and McCance-Katz, E. (2010) Medication Assisted Treatment and HIV/AIDS: Issues in the Diagnosis, Care and Treatment of HIV-Infected Drug Users. AIDS, 24, 331-340. http://dx.doi.org/10.1097/QAD.0b013e32833407d3

[81] Kresina, T.F., Lubran, R., Clark, H.W. and Cheever, L.W. (2012) Substance Assisted Treatment, HIV/AIDS and the Continuum of Response for People Who Inject Drugs. Advances in Preventive Medicine, 2012, Article ID 541489. http://www.hindawi.com/journals/apm/2012/541489/ http://dx.doi.org/10.1155/2012/541489

[82] Shapiro, B., Coffa, D. and McCance-Katz, E.F. (2013) A Primary Care Approach to Substance Misuse. American Family Physician, 88, 113-121.

[83] National Institute on Drug Abuse (NIDA) (1999) Principles of Drug Addiction Treatment, A Research Based Guide. NIH Publication 99-4180.

[84] Ghodse, H. (2002) Drug and Addictive Behavior: A Guide to Treatment. 3rd Edition, Cambridge University Press, Cambridge. http://dx.doi.org/10.1017/CBO9780511543791

[85] Verrico, C.D., Haile, C.N., Newton, T.F., Kosten, T.R. and De La Garza, R. (2013) Pharmacotherapeutics for Substance-Use Disorders: A Focus on Dopaminergic Medications. Expert Opinion on Investigative Drugs, 22, 1549-1568. http://dx.doi.org/10.1517/13543784.2013.836488

[86] Hyman, S.E. and Malenka, R.C. (2001) Addiction and the Brain: The Neurobiology of Compulsion and Its Persistence. National Reviews in Neuroscience, 2, 695-703. http://dx.doi.org/10.1038/35094560

[87] Swift, R., Oslin, D.W., Alexander, M. and Forman, R. (2011) Adherence Monitoring in Naltrexone Pharmacotherapy Trials: A Systematic Review. Journal of Studies in Alcohol and Drugs, 72, 1012-1018.

[88] Kresina, T.F., Bruce, R.D., Pirard, S., Mulvey, K.V, Huesca, R.S. and Lubran, R. (2012) International Expansion of the Use of Pharmacotherapies for the Treatment of Opioid Dependence. Clinical and Experimental Pharmacology, S5, 1.

[89] Bachireddy, C., Soule, M.C., Izenberg, J.M., Dvoryak, S., Dumchev, K. and Altice, F.L. (2014) Integration of Health Services Improves Multiple Healthcare Outcomes among HIV-Infected People Who Inject Drugs in Ukraine. Drug and Alcohol Dependence, 134, 106-114. http://dx.doi.org/10.1016/j.drugalcdep.2013.09.020

[90] Yen, Y.F., Yen, M.Y., Su, L.W, Li, L.H., Chuang, P., Jiang, X.R. and Deng, C.Y. (2012) Prevalences and Associated Risk Factors of HCV/HIV Co-Infection and HCV Mono-Infection among Injecting Drug Users in a Mono-Infection among Injecting Drug Users in a Methadone Maintenance Treatment Program in Taipei, Twain. BMC Public Health, 12, 1066-1073. http://dx.doi.org/10.1186/1471-2458-12-1066

[91] Zhuang, X., Liang, Y., Chow, E.P., Wang, Y., Wilson, D.P. and Zhang, L. (2012) HIV and HCV Prevalence among Entrants to Methadone Maintenance Treatment Clinics in China: A Systematic Review and Meta-Analysis. BMC Infectious Diseases, 12, 130. http://dx.doi.org/10.1186/1471-2334-12-130

[92] Zhuang, X., Wang, Y., Chow, E, P., Liang, Y., Wilson, D.P. and Zhang, L. (2012) Risk Factors Associated with HIV/ HCV Infection among Entrants in Methadone Maintenance Treatment Clinics in China: A Systematic Review and Me- 
ta-Analysis. Drug and Alcohol Dependence, 126, 286-295. http://dx.doi.org/10.1016/j.drugalcdep.2012.05.028

[93] Bao, Y.P., Du, C., Lu, H.Y., Lian, Z., Qiu, Y., Mu, Y., Yan, S.Y. and Liu, Z.M. (2012) The Investigation of HIV and HCV Infection and Risk Factors Among Opiate Drug Users in Beijing, China. The American Journal of Drug and Alcohol Abuse, 38, 140-145. http://dx.doi.org/10.3109/00952990.2011.643984

[94] Xia, Y.H, Chen, W., Tucker, J.D., Wang, C. and Ling, L. (2013) HIV and Hepatitis C Virus Test Uptake at Methadone Clinics in Southern China: Opportunities for Expanding Detection of Bloodborne Infections. BMC Public Health, 13, 899-907. http://dx.doi.org/10.1186/1471-2458-13-899

[95] Malta, M., da Costa, M.R. and Bastos, F.L. (2013) The Paradigm of Universal Access to HIV-Treatment and Human Rights Violation: How Do We Treat HIV-Positive People Who Use Drugs. Current HIV/AIDS Report, 11, 52-62.

[96] Puoti, M., Rossotti, R., Travi, G., Panzeri, C., Morreale, M., Chiari, E., Cocca, G., Orso, M. and Moioli, M.C. (2013) Optimizing Treatment in HIV/HCV Coinfection. Digestive \& Liver Diseases, 45, S355-S362. http://dx.doi.org/10.1016/j.dld.2013.09.001

[97] Stricker, S.M., Fox, K.A., Baggaley, R., Negussie, E., de Pee, S., Grede, N. and Bioem, M.W. (2013) Retention in Care and Adherence to ART Are Critical Elements of HIV Care Interventions. AIDS Behavior, Epub Ahead of Print.

[98] Allen, J., Smith, C. and Bhagani, S. (2014) Will Antireroviral Therapy Reduce HIV-Related Liver Risk? Current Opinion in HIV \& AIDS, 9, 48-53. http://dx.doi.org/10.1097/COH.0000000000000022

[99] Murray, M., Hogg, R.S., Lima, V.D., May, M.T., Moore, D.M., Abgrall, S., Bruyand, M., D’Arminio, Monforte, A., Tural, C., Gill, M.J., Harris, R.J., Reiss, P., Justice, A., Kirk, O., Saag, M., Smith, C.J., Weber, R., Rockstroh, J., Khaykin, P., Sterne, J.A. and the Antiretroviral Therapy Cohort Collaboration (ART-CC) (2012) The Effect of Injecting Drug Use History on Disease Progression and Death among HIV-Positive Individuals Initiating Combination Antiretroviral Therapy: Collaborative Cohort Analysis. HIV Medicine, 13, 89-97. http://dx.doi.org/10.1111/j.1468-1293.2011.00940.x

[100] Hernandez, M.D. and Sherman, K.E. (2011) HIV/Hepatitis Coinfection Natural History and Disease Progression. Current Opinion in HIV \& AIDS, 6, 478-482. http://dx.doi.org/10.1097/COH.0b013e32834bd365

[101] Lincoln, D., Petoumenos, K., Dore, G.J. and Australian HIV Observational Database (2003) HIV/HBV and HIV/HCV Confection, and Outcomes Following Highly Active Antiretroviral Therapy. HIV Medicine, 4, 241-249. http://dx.doi.org/10.1046/j.1468-1293.2003.00152.x

[102] Easterbrooke, P., Sands, A. and Harmanci, H. (2012) Challenges and Priorities in the Management of HIV/HBV and HIV/HCV Coinfection in Resource-Limited Settings. Seminars in Liver Disease, 32, 147-157. http://dx.doi.org/10.1055/s-0032-1316476

[103] US Department of Health and Human Services. Guidelines for the Use of Antiretroviral Agents in HIV-1 Infected Adults and Adolescents. http://aidsinfo.nih.gov/ContentFiles/AdultandAdolescentGL.pdf

[104] (2014) European AIDS Clinical Society. Version 7.02. http://eacsociety.org/Portals/0/140601_EACS\%20EN7.02.pdf

[105] Ghany, M.G., Strader, D.B., Thomas, D.L. and Seeff, L.B. (2009) Diagnosis, Management, and Treatment of Hepatitis C: An Update. Hepatology, 49, 1335-1374. http://dx.doi.org/10.1002/hep.22759

[106] Zeremski, M., Martinez, A.D. and Talal, A.H. (2014) Management of Hepatitis C Virus in HIV-Infected Patients in the Era of Direct-Acting Antivirals. Clinical Infectious Diseases, 58, 880-882.

[107] Soriano, V., Labarga, P., Vispo, E., Ferández-Montero, J.V. and Barreiro, P. (2012) Treatment of Hepatitis C in Patients Infected with Human Immunodeficiency Virus in the Direct-Acting Antiviral Era. Infectious Diseases Clinics of North America, 26, 931-948. http://dx.doi.org/10.1016/j.idc.2012.08.004

[108] Fierer, D.S., Dieterich, D.T., Mullen, M.P., Branch, A.D., Uriel, A.J., Carriero, D.C., van Seggelen, W.O., Hijdra, R.M., Cassagnol, D.G. and the New York Acute Hepatitis C Surveillance Network (2013) Telaprevir in the Treatment of Acute Hepatitis C Virus Infection in HIV-Infected Men. Clinical Infectious Diseases, 58, 873-879.

[109] Luetkemeyer, A.F., Havlir, D.V. and Currier, J.S. (2012) Complications of HIV Disease and Antiretroviral Therapy. Topics in Antiviral Medicine, 20, 48-60.

[110] Rodriguez-Torres, M. (2013) Focus on Drug Interactions: The Challenge of Treating Hepatitis C Virus Infection with Direct-Acting Antiviral Drugs in the HIV Positive Patient. Current Opinion in Infectious Diseases, 26, 50-57.

[111] Salmon-Ceron, D., Arvieux, C., Bourliere, M., Cacoub, P., Halfon, P., Lacombe, K., Pageaux, G.P., Pialoux, G., Piroth, L., Poizot-Martin, I., Rosenthal, E. and Pol, S. (2013) Use of First-Generation HCV Protease Inhibitors in Patients CoInfected by HIV and HCV Genotype 1. Liver International, 34, 869-889.

[112] Coco, B., Caraceni, P., Aghemo, A., Bitetto, D., Bruno, R., Ciancio, A., Marzioni, M., Petta, S., Rendina, M. and Valenti, L. (2014) Triple Therapy with First-Generation Protease Inhibitors for Patients with Genotype 1 Chronic Hepatitis C: Recommendations of the Italian Association for the Study of the Liver (AISF). Digestive Liver Diseases, 46, 
18-24. http://dx.doi.org/10.1016/j.dld.2013.08.243

[113] AIDSMAP (2014) Sofosbuvir \& Ribavirin Cures 75\% of Genotype 1 HIV/HCV Co-Infected Patients. Report from the 21st Conference on Retroviruses and Opportunistic Infections (CROI 2014), Boston. http://www.aidsmap.com/page/2832937/ 
Scientific Research Publishing (SCIRP) is one of the largest Open Access journal publishers. It is currently publishing more than 200 open access, online, peer-reviewed journals covering a wide range of academic disciplines. SCIRP serves the worldwide academic communities and contributes to the progress and application of science with its publication.

Other selected journals from SCIRP are listed as below. Submit your manuscript to us via either submit@scirp.org or Online Submission Portal.
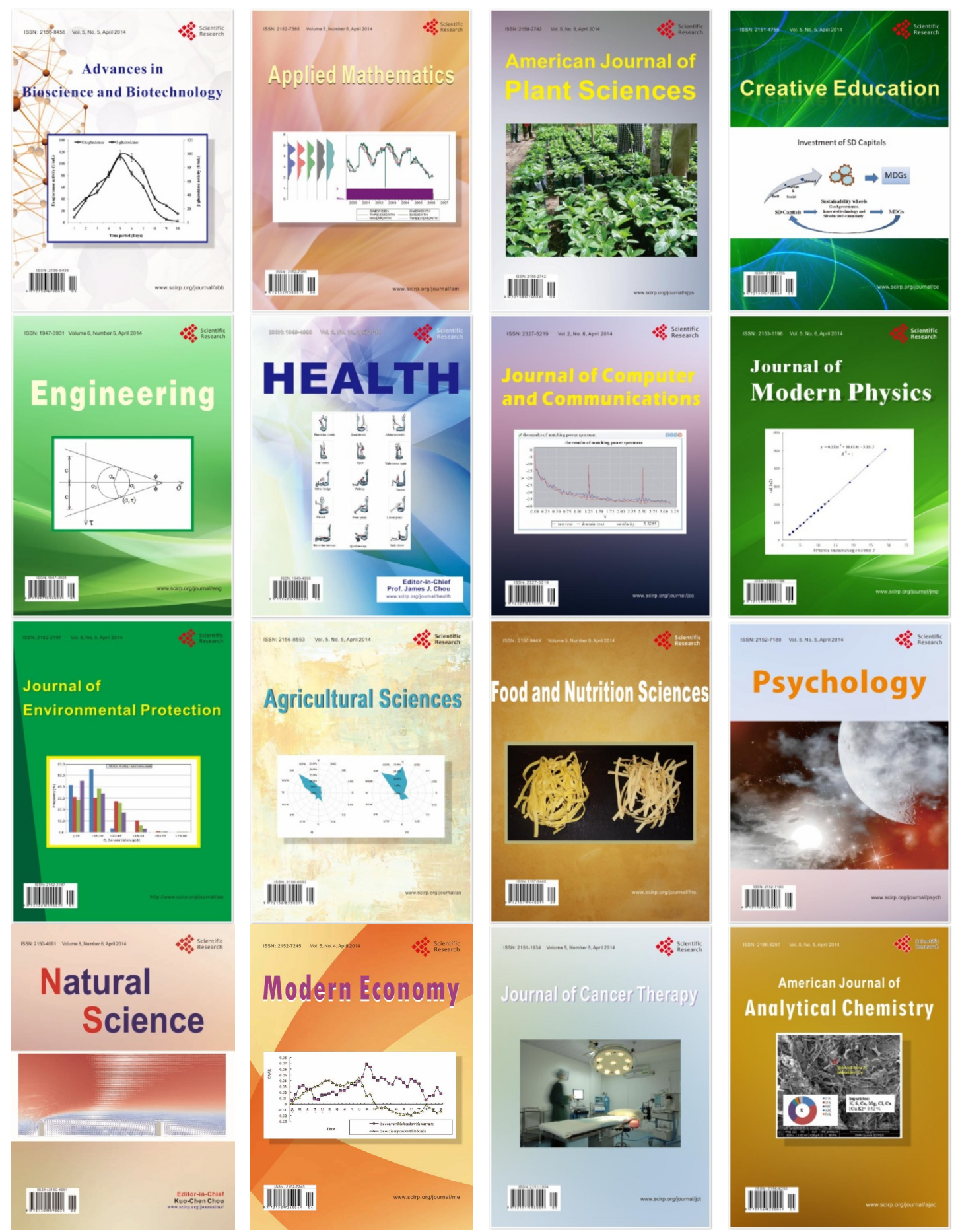